\title{
Movements, at-sea distribution and behaviour of a tropical pelagic seabird: the wedge-tailed shearwater in the western Indian Ocean
}

\author{
Teresa Catry ${ }^{1, *}$, Jaime A. $\operatorname{Ramos}^{1}$, Matthieu Le Corre ${ }^{2}$, Richard A. Phillips ${ }^{3}$ \\ ${ }^{1}$ Instituto do Mar (IMAR), Departamento de Zoologia, Universidade de Coimbra, 3004-517 Coimbra, Portugal \\ ${ }^{2}$ Laboratoire ECOMAR, Université de la Réunion, 97715 Saint Denis message cedex 9, France \\ ${ }^{3}$ British Antarctic Survey, Natural Environment Research Council, High Cross, Madingley Road, Cambridge CB3 0ET, UK
}

\begin{abstract}
This is the first study using geolocators (global location sensing, GLS) to track the movements of a pelagic tropical seabird. We used GLS to describe at-sea distribution and activity patterns of wedge-tailed shearwaters Puffinus pacificus breeding on Aride Island, Seychelles, in the late chick-rearing, non-breeding and pre-breeding periods. During late chick-rearing and pre-breeding periods, shearwaters foraged relatively close to the colony. In the non-breeding period, shearwaters were found on a west-east gradient along the equator, between $5^{\circ} \mathrm{N}$ and $10^{\circ} \mathrm{S}$. Some of the tracked individuals showed little dispersion, staying as close as $1000 \mathrm{~km}$ to Aride Island, while others travelled $3500 \mathrm{~km}$ to the Central Indian Ocean Basin. Individual core areas of activity showed little overlap. Overall, wedge-tailed shearwaters showed short-distance movements and exploited relatively unproductive oceanic waters. At-sea distribution largely matched that of yellowfin and skipjack tunas, emphasising the importance of the association with subsurface predators rather than associations with physical oceanographic features that enhance primary productivity. During the non-breeding period, the feeding activity of shearwaters was mainly concentrated in the daylight period, when tunas also forage. A different behaviour, characterised by a much lower proportion of the night sitting on the sea surface, was recorded in the pre-laying exodus of 1 female to more productive waters, suggesting a different feeding strategy and/or targeting of different prey. Knowledge of the at-sea distribution of wedge-tailed shearwaters allows quantification of the overlap with industrial fisheries, which will be crucial to devise fisheries policies for the Indian Ocean with important implications for the conservation of this species.
\end{abstract}

KEY WORDS: Wedge-tailed shearwater · Activity patterns · At-sea distribution · Foraging behaviour $\cdot$ Pelagic $\cdot$ Habitat preferences $\cdot$ Indian Ocean · Tuna distribution

\section{INTRODUCTION}

Migration is known to be most pronounced in environments in which food supplies vary greatly through the year, enabling animals to exploit periodic abundances and avoid shortages (Newton 2008). In tropical marine environments, food resources have less seasonal variation than in temperate and polar regions (Ashmole 1971, Weimerskirch 2007), which can partly explain why most tropical seabirds, with the exception of populations breeding at the limit of tropical zones, do not perform mi- grations to the same extent as their temperate or polar counterparts. On the other hand, food resources in tropical oceans are scarcer and more patchily distributed (Ashmole 1971, Weimerskirch 2007), which might impose high foraging costs, either by increasing the proportion of time spent searching or in prey patches, or an extension of the prospected area. For example, dispersal of tropicbirds (Phaethon lepturus and $P$. aethereus) outside the breeding season is usually multidirectional (Spear \& Ainley 2005). Assuming this is representative of other tropical seabirds, it suggests that their migrations are to 
some extent less predictable than those of many temperate or polar seabirds, where most or all of the population moves to 1 or more distant wintering areas (Phillips et al. 2005, 2006, 2007, Shaffer et al. 2006). Furthermore, whereas temperate and polar seabirds rely mostly on predictable physical oceanographic features (fronts, shelf and ice edges, upwelling zones, etc.), tropical seabird species seem to rely to a much greater extent on fish and squid forced to the surface by diving predators (Ballance \& Pitman 1999, Spear et al. 2001, Jaquemet et al. 2004), the location and timing of which is unpredictable (Weimerskirch 2007).

Current knowledge of the at-sea distribution and movements of tropical seabirds is based primarily on shipboard observations (Bailey 1968, Pocklington 1979, Dunlop et al. 2001, Jaquemet et al. 2004), seawatching from the coast and band recoveries (Rogers 1975). Although at-sea observations provide data on the distribution and multispecific assemblages of seabirds during the non-breeding season, the information is limited given the inability to determine the origin and breeding status of individuals. This can only be achieved by dyeing large numbers of birds at colonies, or by tracking. During the last decade, the development of tracking devices (such as satellite transmitters and light-based geolocators) has enabled much more detailed descriptions of the at-sea distribution and behaviour of pelagic seabirds during the non-breeding period (e.g. Grémillet et al. 2000, Weimerskirch \& Wilson 2000, González-Sólis et al. 2007, Phillips et al. 2007, Mallory et al. 2008). Most of these studies have focused on temperate, polar and subtropical species, whereas tropical seabirds have received very little attention (but see Weimerskirch et al. 2006).

Wedge-tailed shearwaters Puffinus pacificus have a large breeding distribution and foraging range, extending throughout the tropical and subtropical latitudes of the Indian and Pacific oceans (Harrison 1983). Of these, the tropical populations are thought to be mainly sedentary throughout the year, and the subtropical populations more widely distributed (Harrison 1983). Little is known, however, about the movements and at-sea behaviour of individual wedge-tailed shearwaters. Global population trends of wedge-tailed shearwaters are unquantified but there is some evidence of a population decline due to poaching, predation and over-fishing of tuna (Birdlife International 2007). The knowledge of how pelagic seabirds make use of the marine environment and the identification of core foraging areas may be therefore crucial for understanding their foraging strategies and developing a concerted conservation strategy.

In the present study we used geolocators (also termed global location sensing [GLS] loggers) to describe movements and activity patterns of wedge-tailed shearwaters breeding on Aride Island, Seychelles, western Indian Ocean. In particular, we aimed to (1) identify the key areas used by wedge-tailed shearwaters during the late chick-rearing, non-breeding and pre-breeding periods, (2) determine habitat preferences (by identifying which oceanographic parameters determine site selection), (3) examine individual variability in site preference and (4) describe activity patterns of non-breeding birds. Our predictions were: (1) Given that ocean productivity in the Seychelles archipelago is low and that wedge-tailed shearwaters are not central-place foragers during the non-breeding season, we expect them to move towards more productive waters, namely to the coastal areas off Arabia, India, Sri Lanka and/or Indonesia. (2) Wedgetailed shearwaters are the third most abundant seabird in the western Indian Ocean, totalling ca. 145000 pairs (authors' unpubl. data) and both intra- and inter-specific competition may be especially high in such an unproductive environment. Thus we predict that, despite searching for more productive areas, wedge-tailed shearwaters may show spatial partitioning in their at-sea distribution. (3) In the Indian Ocean, wedge-tailed shearwaters are known to forage in association with subsurface predators, mainly yellowfin tuna Thunnus albacares and skipjack tuna Katsuwonus pelamis (S. Jaquemet pers. comm.) and thus we expect to find a high overlap in shearwater and tuna fisheries distribution.

This is the first study to present detailed information on the at-sea behaviour, distribution and habitat characteristics of a tropical pelagic seabird during the late chick-rearing, non-breeding and pre-breeding periods. The data were used to discuss the strategies used by tropical pelagic seabirds in general for foraging in an environment of much lower seasonal variability, and with scarcer and more patchily distributed resources than those typical of temperate or polar latitudes. Furthermore, data on the at-sea distribution of wedgetailed shearwaters will allow the quantification of the overlap with industrial fisheries in the Indian Ocean.

\section{MATERIALS AND METHODS}

Oceanography of the Indian Ocean. Fig. 1 shows two large circular currents, one in the northern hemisphere that flows clockwise and one south of the equator that moves anticlockwise, constitute the dominant flow pattern in the Indian Ocean, and are strongly influenced by the Asiatic Monsoon. During the northwest monsoon or austral summer, the wind blows from east to west and induces the development of the North Equatorial Current (NEC; Tomczak \& Godfrey 2003; our Fig. 1a). A strong countercurrent, the Equatorial Counter Current (ECC), flows west-east, to the south of the NEC at this time of the year. During the southeast monsoon or austral winter the 
Fig. 1. Chl a concentrations and main ocean currents in the study area during 2007: (a) January and February, (b) April and May and (c) June and July. NEC: North Equatorial Current, SEC: South Equatorial Current, ECC: Equatorial Countercurrent, SWMC: Southwest Monsoon Current. Dotted lines: secondary, or weaker currents
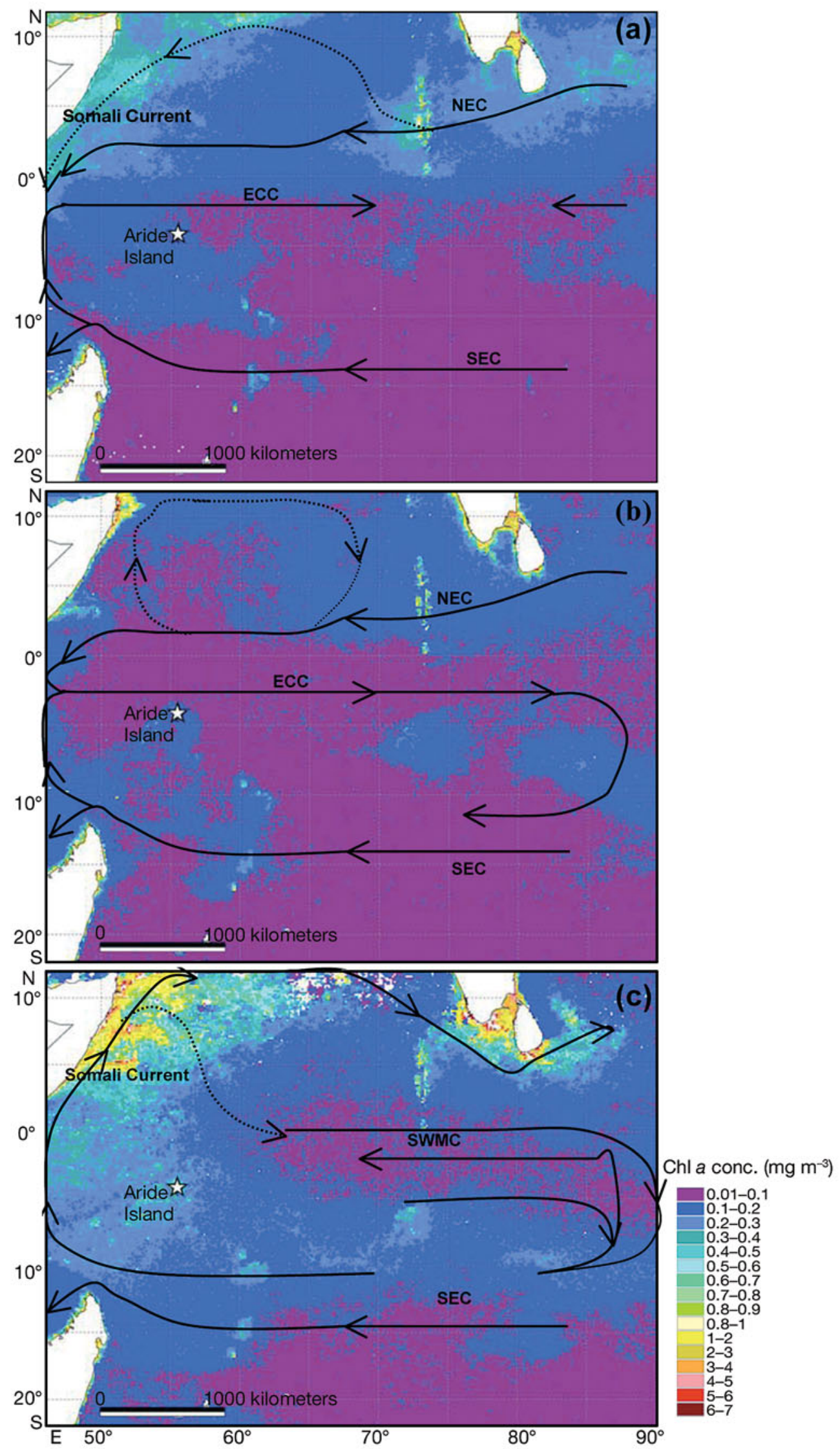
NEC reverses and flows west to east as the Southwest Monsoon Current (SWMC; Tomczak \& Godfrey 2003; our Fig. 1c). Reversing monsoonal winds are also responsible for changes in the direction of the Somali Current and the latitude of the ECC. Overall, chlorophyll a (chl a) concentrations are low in the western and central Indian Ocean (Fig. 1a,b), especially in comparison with equatorial regions of the Pacific and Atlantic oceans. The strongest upwelling of the Indian Ocean occurs when the southeast monsoon produces strong Ekman transport away from the coasts of Somalia, Arabia, India and Sri Lanka (Tomczak \& Godfrey 2003; our Fig. 1c).

Logger deployment and data analysis. Fieldwork was carried out on Aride Island ( $4^{\circ} 10^{\prime} \mathrm{S}, 55^{\circ} 40^{\prime} \mathrm{E}$ ), the most northerly of the granitic islands of the Seychelles archipelago, where ca. 19500 pairs of wedge-tailed shearwaters breed (Bowler et al. 2002). Sixteen GLS loggers (MK4, BAS) were deployed on wedge-tailed shearwaters from 20 to 25 January (towards the end of chickrearing) and recovered from 4 July to 17 August 2007. In the Seychelles, wedge-tailed shearwaters breed during the austral summer, usually between September and February (Burger \& Lawrence 2000). After breeding, wedge-tailed shearwaters spend a few months away from Aride Island, and usually return in May or June. Thereafter, visits to the colony become more frequent closer to laying. Each geolocator, weighing $4.5 \mathrm{~g}$, was attached with a single cable tie to a metal ring and deployed on the tarsus (representing ca. $1.6 \%$ of the bird's weight). All shearwaters were captured at the entrance or inside nest-burrows after feeding their chicks, and a single bird per pair was equipped with a logger. Gender was determined by molecular methods using a blood sample collected from the tarsal vein. In order to assess potential negative effects of loggers, all chicks of tracked birds were weighed after logger deployment and ca. $25 \mathrm{~d}$ later (or before fledging) and the variation in body mass compared to that of a sample of 12 control chicks of similar age $\left(t_{26}=1.069, \mathrm{p}=0.295\right.$, based on wing length) in the same period. The devices deployed had light (geolocation), salt-water immersion (activity) and temperature-recording capabilities. Geolocation is the calculation of position from ambient light level readings with reference to time (Wilson et al. 1992, Hill 1994). Latitude and longitude of each bird was estimated (twice $^{-1}$ ) from, respectively, day (night) length, and the time of local midday (midnight) relative to Greenwich Mean Time (GMT) (Phillips et al. 2004). Light data were analysed using MultiTrace software according to Phillips et al. (2004). During processing, locations derived from curves with apparent interruptions around sunset and sunrise, or that required unrealistic flight speeds (>35 $\mathrm{km} \mathrm{h}^{-1}$ sustained over a $48 \mathrm{~h}$ period), were identified and later excluded if appropriate. Locations were affected and thus excluded for variable periods ( 2 to $5 \mathrm{wk}$ ) before and after the 21 March equinox. Validated data were smoothed twice (Phillips et al. 2004). Previous studies using geolocators indicate mean accuracies of $186 \pm$ $114 \mathrm{~km}$ (Phillips et al. 2004) and of $202 \pm 171 \mathrm{~km}$ (Shaffer et al. 2005), which seems adequate for studying largescale movements of pelagic seabirds. However, none of these studies was carried out in equatorial regions, where GLS errors can presumably be larger due to the lower accuracy to determine day length (which is fundamental to estimating latitude). Further studies should investigate GLS accuracy at lower latitudes.

Activity patterns of wedge-tailed shearwaters were derived from immersion data. The immersion data consist of values between 0 and 200 corresponding to the number of instantaneous tests every $3 \mathrm{~s}$ for salt-water immersion that were positive within each $10 \mathrm{~min}$ period. These data were matched with the timing of civil twilight (when sun is $6^{\circ}$ below the horizon) in order to calculate the proportion of time and the total time spent on the water and in flight during darkness and daylight each day.

For the analysis we considered 3 periods: (1) late chick-rearing, the period between logger deployment and the departure on migration, identified either from nest monitoring and/or from location and activity (immersion data), (2) non-breeding, the period between the end of the equinox period (April) and the return to the breeding grounds, identified from location and activity data, and (3) pre-breeding, the period between the first long ( $>1 \mathrm{~d}$ ) visit of the bird to land and logger recovery, identified from activity data. Activity patterns of shearwaters were not analysed in the late chick-rearing and pre-breeding periods (except for 1 female during the pre-laying exodus; see 'Results: Pre-breeding period') given the difficulties in differentiating periods of flight and periods in the breeding colony from immersion data.

Locations of birds at sea were examined using ArcView GIS 3.2 (ESRI). Key areas for the 3 periods were identified by generating kernel density maps in an equal-area cylindrical projection using the Animal Movement extension in ArcView (Phillips et al. 2004). We considered the 95 and $50 \%$ kernel density contours to represent the area of active use and the core areas of activity, respectively (Hamer et al. 2007). These areas may be overestimated given the relative inaccuracy of the GLS measurements (see 3 paragraphs above). We used 3 variables to characterise marine habitats: chl a concentration, sea surface temperature (SST) and bathymetry. Chl a concentrations were derived from the sea-viewing wide field-of-view sensor (SeaWiFS) monthly composites with a $9 \mathrm{~km}$ spatial resolution (http://reason.gsfc.nasa.gov/OPS/Giovanni/ocean. seawifs.shtml). Monthly averages of SST data were Aqua's moderate resolution imaging spectroradiometer (MODIS)-mapped products at $4 \mathrm{~km}$ resolution, 
downloaded from http://poet.jpl.nasa.gov/.Bathymetry was determined using ETOPO2 grids (www.ngdc. noaa.gov/mgg/gdas/gd_designagrid.html).

Statistical analyses were performed with STATISTICA 6.0. One-way ANOVAs, followed by post hoc Tukey tests, were used to compare oceanographic characteristics (water depth, SST and chl a concentrations extracted for each kernel core) of areas used by wedge-tailed shearwaters during the different tracking periods, and between individuals with different atsea distributions during the non-breeding period. Also, $t$-tests were performed to investigate differences in activity patterns between (1) individuals with different distributions during the non-breeding period and (2) non-breeding and pre-laying exodus periods of 1 tracked female. Values are presented as mean \pm SD. Results were considered significant at $\mathrm{p}<0.05$.

\section{RESULTS}

\section{Logger retrieval and device effects}

We retrieved all the 16 loggers deployed but 7 of these failed to download. This failure rate reflects the greater age of a number of these loggers that were built for an earlier study. All loggers were retrieved in the pre-breeding period, with the exception of 1 device, deployed on a female, which was recovered while the bird was incubating a recently laid egg. Six female and 3 male wedge-tailed shearwaters were tracked for a mean of $180.1 \pm 17.0 \mathrm{~d}$ (range: 163 to $206 \mathrm{~d}$ ). Of the 2149 locations obtained outside the equinox periods, 5.4 and $0.3 \%$ were excluded subsequently because of light interference and unrealistic flight speeds, respectively, providing a total of 2025 validated locations.

Variation in body mass was similar for the 16 chicks of tracked birds and 12 control chicks of similar age $\left(t_{26}=0.556, \mathrm{p}=0.583\right)$. Four of the chicks of tracked birds fledged during the monitoring period.

\section{At-sea distribution and movements}

\section{Late chick-rearing period}

Wedge-tailed shearwaters were tracked for a mean of $23.9 \pm 11.2 \mathrm{~d}$ (range: 8 to $37 \mathrm{~d}$ ) during late chick rearing. Although the area used by the 9 tracked individuals comprised $>1500000 \mathrm{~km}^{2}$, the core area of activity (50\% kernels) was much smaller, at ca. $160000 \mathrm{~km}^{2}$ (Fig. 2a). Foraging areas were exclusively located to the east of Aride Island, with a preference for waters to the northeast. Breeding shearwaters apparently avoided the shallow waters of the Mascarene Plateau, instead targeting areas with depths $\geq 3500 \mathrm{~m}$. Despite the small sample size ( 3 males and 6 females), there was some evidence for sex-related differences in the core areas (50\% kernels), with females showing a broader distribution than males (Fig. 2a).

Non-breeding period

On average, tracked shearwaters were followed for $37.9 \pm 13.7 \mathrm{~d}$ (range: 13 to $56 \mathrm{~d}$ ) during the non-breeding period. Birds dispersed eastwards, occupying the area between Aride Island and the Ninety East Ridge (ca. $80^{\circ} \mathrm{E}$; Fig. 2b). We found a west-east distribution gradient in core areas (50\% kernels) amongst the 9 birds tracked, and individual movements were classified as either long- or short-distance dispersal (Fig. 2b). The 4 birds that performed short-distance dispersal were distributed between Aride Island and the Chagos-Laccadive Ridge. In contrast, the other 5 wedgetailed shearwaters travelled further east and were concentrated mainly between the Chagos-Laccadive and the Ninety East Ridge (Fig. 2b). Overall, although individual activity areas (95\% kernels) overlapped extensively, core areas overlapped partially only for the 3 individuals that were concentrated in the Central Indian Basin (Fig. 3). There was no evidence of sexrelated differences in distribution during the nonbreeding period.

\section{Pre-breeding period}

Following the exclusively pelagic non-breeding period, wedge-tailed shearwaters returned in May and June to the waters surrounding Aride Island, and most of the birds spent at least 1 long period (2 to $4 \mathrm{~d}$ ) on land. During the pre-breeding period birds were tracked for a mean of $51.4 \pm 24.7 \mathrm{~d}$ (range: 22 to $85 \mathrm{~d}$ ). The distribution of wedge-tailed shearwaters during this time was not very different from that in the latechick rearing period (Fig. 2c). Core areas (50\% kernels) were also located to the east of Aride Island, but whereas during the chick-rearing period birds preferentially foraged on northeast waters outside the Mascarene Plateau, during the pre-breeding period they exploited both the northeast area and the southern shallower waters of the Mascarene Plateau (Fig. 2c). Only 3 birds travelled northwest to the deeper waters of the Somali Basin.

One of the tracked females started breeding unusually early, laying in the 2nd wk of August. Just before laying, this female undertook a pre-laying exodus of $22 \mathrm{~d}$ towards the Somali Basin, travelling ca. $7000 \mathrm{~km}$ in total (Fig. 4). 
(a)


Kernel density contour (\%)

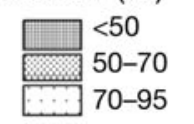

(b)

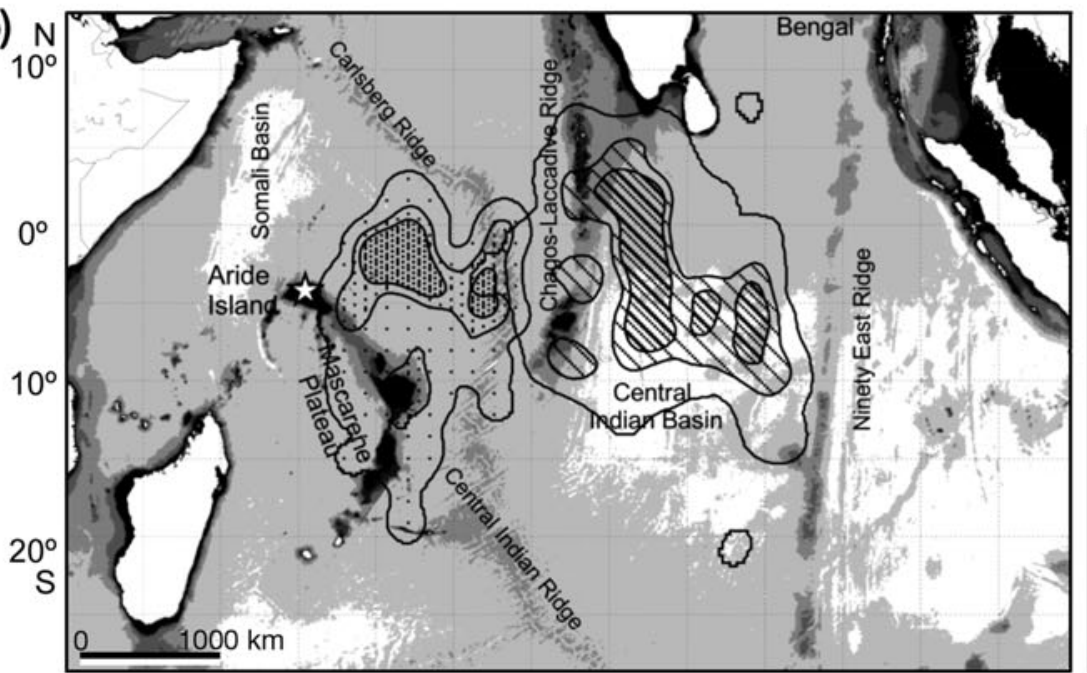

(c)

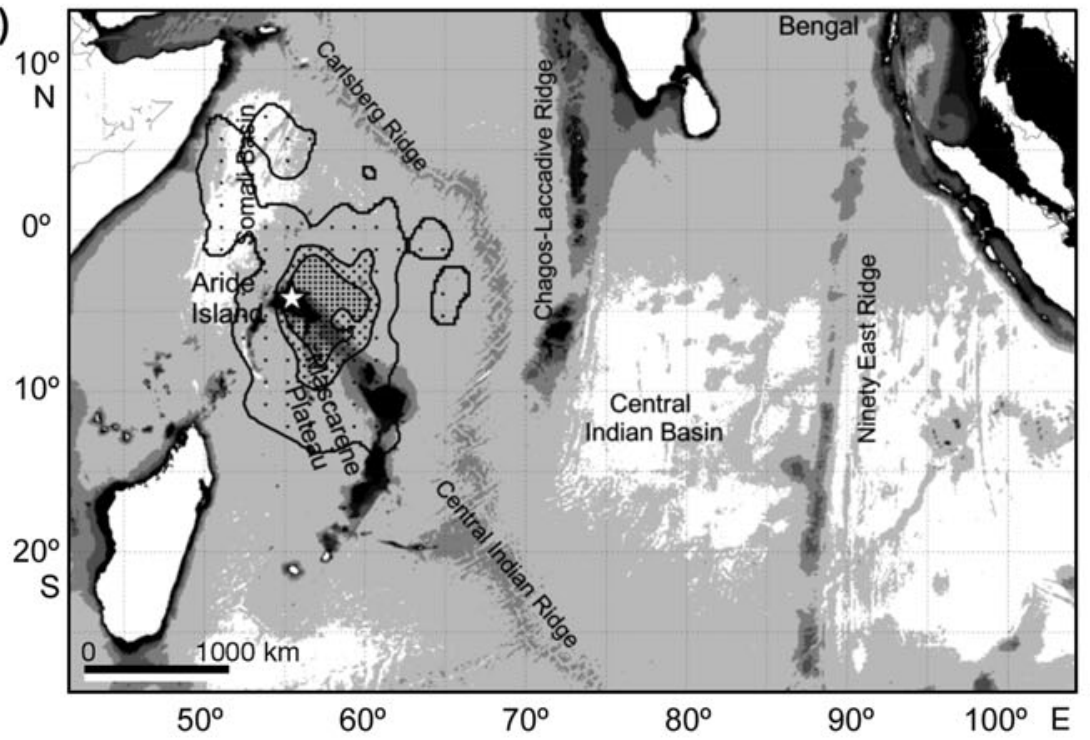



All panels Bathymetry

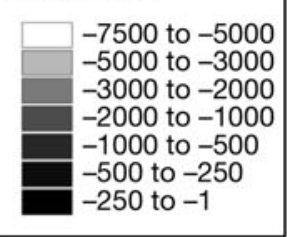

(b)

Kernel density contour (\%)

Short-distance

dispersal

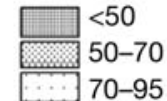

Long-distance

dispersal

$\mathrm{M}<50$

50-70

$70-95$

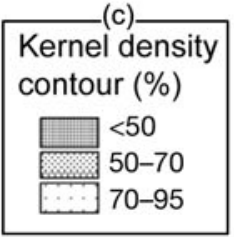

Fig. 2. Puffinus pacificus. Density distribution (kernel contours) of 9 birds during the (a) late chick-rearing, (b) non-breeding and (c) pre-breeding periods, with bathymetric details of the study area overlaid. Distinct sex-based distributions were evident only for the late chick-rearing period (a) 


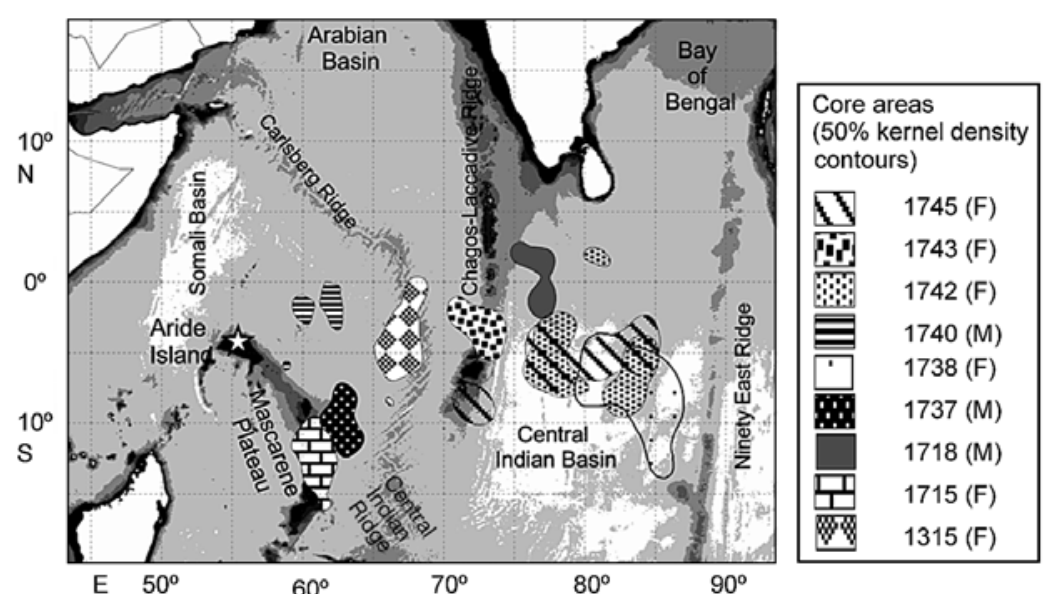

Fig. 3. Puffinus pacificus. Individual core areas (50\% kernel) of activity of 9 birds during the non-breeding period overlaid on bathymetry. F: female, M: male acterised by generally low productivity (mean concentration of chl $a=0.11$ to $0.21 \mathrm{mg} \mathrm{m}^{-3}$ ) and warm water temperatures (mean $\mathrm{SST}=28.2$ to $29.9^{\circ} \mathrm{C}$ ). Core areas (50\% kernels) of tracked birds were significantly more productive and cooler during the pre-breeding period than during the chick-rearing and nonbreeding periods $\left(F_{2,776}=135.8, \mathrm{p}<\right.$ 0.0001 and $F_{2,788}=210.7, \mathrm{p}<0.0001$, respectively, followed by post hoc Tukey tests).

Individuals that performed longdistance movements spent the nonbreeding period in waters that were significantly deeper, more productive and had lower SST than those of birds that stayed closer to Aride Island (for core

\section{At-sea distribution in relation to oceanography}

Oceanographic characteristics of the areas used by wedge-tailed shearwaters during the different tracking periods are presented in Table 1. Overall, birds showed an oceanic distribution, exploiting regions of deep water (3500 to $4500 \mathrm{~m}$ ) and avoiding the shallow waters of both continental and oceanic shelves. Water depth in core areas (50\% kernels) was significantly lower during the pre-breeding period than during the late chickrearing and non-breeding periods $\left(F_{2,788}=29.6, \mathrm{p}<\right.$ 0.001 , followed by post hoc Tukey tests). Activity areas (95\% kernels) of wedge-tailed shearwaters were char-

Table 1. Puffinus pacificus. Oceanographic characteristics within the kernel distribution during different tracking periods in 2007. Values are mean \pm SD. SST: sea surface temperature

\begin{tabular}{|c|c|c|c|}
\hline $\begin{array}{l}\text { Kernel } \\
\text { density (\%) }\end{array}$ & $\begin{array}{l}\text { Chl a con- } \\
\text { centration } \\
\left(\mathrm{mg} \mathrm{m}^{-3}\right)\end{array}$ & $\begin{array}{l}\mathrm{SST} \\
\left({ }^{\circ} \mathrm{C}\right)\end{array}$ & $\begin{array}{l}\text { Water depth } \\
\text { (m) }\end{array}$ \\
\hline \multicolumn{4}{|c|}{ Late chick-rearing } \\
\hline 50 & $0.11 \pm 0.05$ & $29.3 \pm 0.4$ & $3965 \pm 660$ \\
\hline 70 & $0.12 \pm 0.04$ & $29.3 \pm 0.4$ & $3908 \pm 904$ \\
\hline 95 & $0.13 \pm 0.05$ & $29.2 \pm 0.6$ & $3932 \pm 885$ \\
\hline \multicolumn{4}{|c|}{ Non-breeding } \\
\hline \multicolumn{4}{|c|}{ Long-distance } \\
\hline 50 & $0.12 \pm 0.03$ & $29.6 \pm 0.9$ & $4581 \pm 849$ \\
\hline 70 & $0.13 \pm 0.11$ & $29.6 \pm 1.0$ & $4071 \pm 1218$ \\
\hline 95 & $0.12 \pm 0.07$ & $29.7 \pm 1.0$ & $4293 \pm 1152$ \\
\hline \multicolumn{4}{|c|}{ Short-distance } \\
\hline 50 & $0.10 \pm 0.03$ & $29.9 \pm 0.8$ & $3411 \pm 1224$ \\
\hline 70 & $0.09 \pm 0.02$ & $29.8 \pm 1.0$ & $3735 \pm 979$ \\
\hline 95 & $0.10 \pm 0.03$ & $29.9 \pm 1.0$ & $3595 \pm 1108$ \\
\hline \multicolumn{4}{|c|}{ Pre-breeding } \\
\hline 50 & $0.21 \pm 0.12$ & $28.3 \pm 1.0$ & $3446 \pm 1468$ \\
\hline 70 & $0.21 \pm 0.11$ & $28.2 \pm 1.1$ & $3531 \pm 1366$ \\
\hline 95 & $0.20 \pm 0.11$ & $28.2 \pm 1.2$ & $3546 \pm 1327$ \\
\hline \multicolumn{4}{|c|}{ Pre-laying exodus } \\
\hline & $0.43 \pm 0.29$ & $26.7 \pm 0.7$ & $4662 \pm 1109$ \\
\hline
\end{tabular}

areas: $t_{304}=9.78, \mathrm{p}<0.001 ; t_{304}=5.27, \mathrm{p}<0.001 ; t_{304}=$ $3.32, \mathrm{p}<0.01$, respectively).

The area exploited by the female during the prelaying trip (Somali Basin) was characterised by greater depth and productivity, and lower SST than any other area exploited by tracked shearwaters $\left(t_{701}=5.33\right.$, p < $0.001 ; t_{684}=11.47, \mathrm{p}<0.001 ; t_{701}=7.86, \mathrm{p}<0.001$, respectively).

\section{Activity patterns}

During the non-breeding period, wedge-tailed shearwaters spent a high proportion (85.5\%) of darkness on the water, and only ca. $1.7 \mathrm{~h}$ in total flying (Table 2). In contrast, during daylight, shearwaters spend almost half of their time in flight (mean of $5.2 \mathrm{~h}$ $\mathrm{d}^{-1}$ ). Shearwaters performing short and long dispersals had similar activity patterns ( $t$-tests: $t_{7}=0.76$ to 1.32 , $\mathrm{p}=0.27$ to 0.47 , for the 6 activity parameters estimated; Table 2) and there was also no evidence of sex-related differences in activity ( $t$-tests: $t_{7}=0.49$ to $1.26, \mathrm{p}=0.28$ to 0.67 ). During darkness, the female tracked in the pre-laying exodus spent a significantly lower proportion of time in the water, less time in total in the water and more time in total in flight than in the non-breeding period ( $t$-tests: $t_{55}=10.17, \mathrm{p}=0.000 ; t_{55}=10.50, \mathrm{p}=$ $0.000 ; t_{55}=9.91, \mathrm{p}=0.000$, respectively), whereas during daylight, patterns were similar between the 2 periods ( $t$-tests: $t_{55}=0.12, \mathrm{p}=0.91 ; t_{55}=0.17, \mathrm{p}=0.86 ; t_{55}=$ 0.38, $\mathrm{p}=0.70$; Table 2).

\section{DISCUSSION}

To our knowledge, this is the first study to use GLS loggers (and one of the few using any tracking device) 


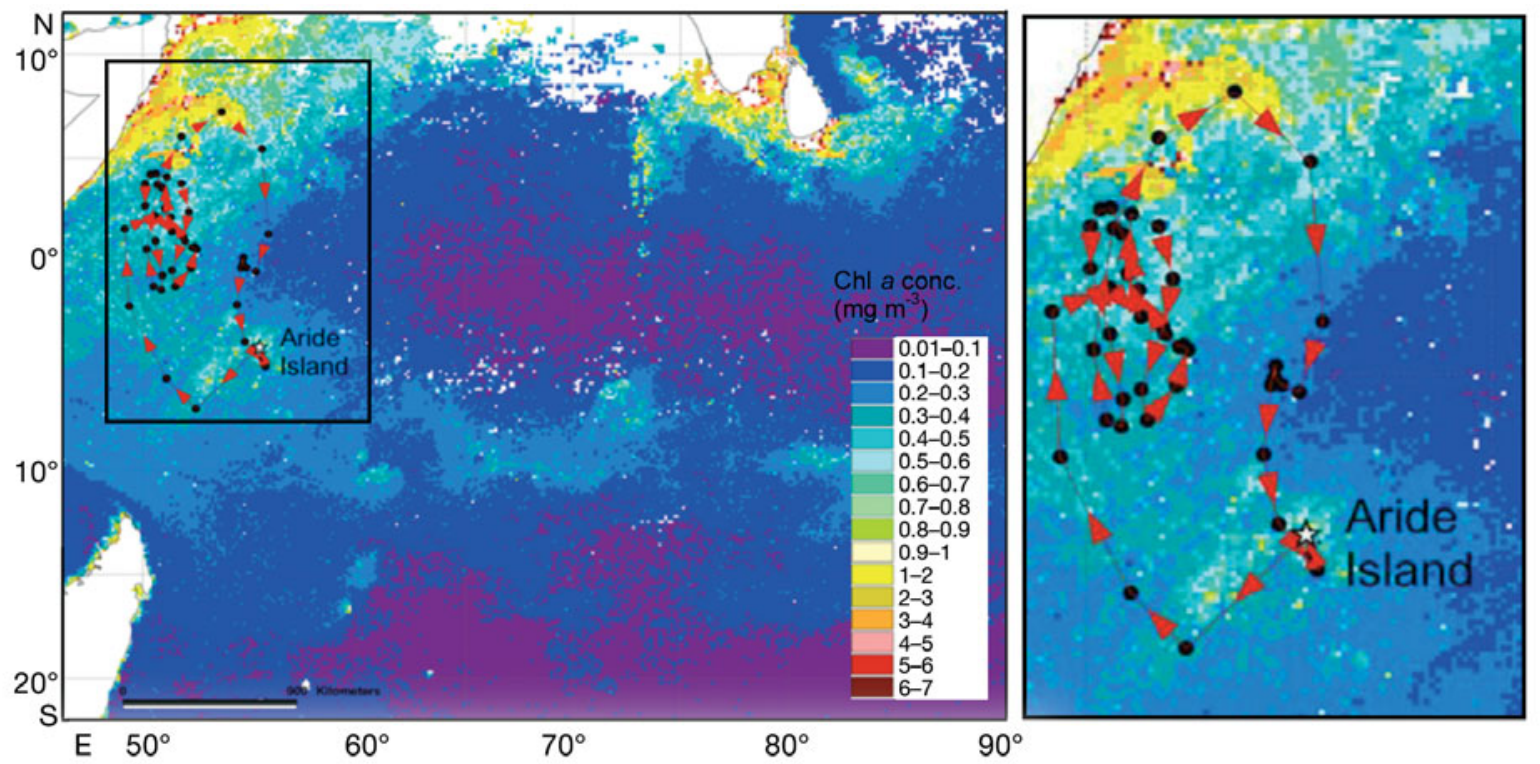

Fig. 4. Puffinus pacificus. Pre-laying exodus of 1 female overlaid on productivity (chl a concentrations) in the study area in July and August

to describe movements, at-sea distribution and activity patterns of a tropical seabird during the non-breeding and pre-laying periods. GLS loggers had no negative effects on shearwaters: following deployment, chicks were fed for a further month (or until fledging), indicating no desertion as a result of handling of adults. In addition, their growth was similar to that of control chicks. Furthermore, we had an exceptionally high logger recovery rate $(100 \%)$, which reveals the high nest-fidelity of wedge-tailed shearwaters and supports the absence of any deleterious effects.

Table 2. Puffinus pacificus. Activity patterns during the non-breeding period. Values are means $\pm \mathrm{SD}$. F: female, $\mathrm{M}$ : male

\begin{tabular}{|c|c|c|c|c|c|c|}
\hline \multirow[t]{2}{*}{ Tracking no. } & \multicolumn{2}{|c|}{ Time on water (\%) } & \multicolumn{2}{|c|}{ Total time on water $(\mathrm{h})$} & \multicolumn{2}{|c|}{ Total time in flight (h) } \\
\hline & Daylight & Darkness & Daylight & Darkness & Daylight & Darkness \\
\hline \multicolumn{7}{|c|}{ Non-breeding period } \\
\hline $1315(F)$ & $58.5 \pm 11.0$ & $89.5 \pm 10.0$ & $7.1 \pm 1.4$ & $10.7 \pm 1.2$ & $5.0 \pm 1.3$ & $1.2 \pm 1.2$ \\
\hline $1715(\mathrm{~F})$ & $56.4 \pm 14.5$ & $88.9 \pm 7.6$ & $6.6 \pm 1.6$ & $10.9 \pm 1.0$ & $5.1 \pm 1.8$ & $1.4 \pm 0.9$ \\
\hline $1718(\mathrm{M})$ & $54.4 \pm 16.5$ & $81.8 \pm 15.2$ & $6.7 \pm 2.1$ & $9.8 \pm 1.8$ & $5.6 \pm 2.0$ & $2.1 \pm 1.8$ \\
\hline $1737(\mathrm{M})$ & $52.3 \pm 11.8$ & $80.3 \pm 10.8$ & $6.3 \pm 1.5$ & $9.6 \pm 1.4$ & $5.8 \pm 1.4$ & $2.3 \pm 1.3$ \\
\hline $1738(\mathrm{~F})$ & $53.0 \pm 11.1$ & $80.4 \pm 13.1$ & $6.3 \pm 1.3$ & $9.7 \pm 1.5$ & $5.6 \pm 1.3$ & $2.4 \pm 1.6$ \\
\hline $1740(\mathrm{M})$ & $71.2 \pm 10.6$ & $89.6 \pm 7.7$ & $8.7 \pm 1.3$ & $10.6 \pm 0.9$ & $3.5 \pm 1.3$ & $1.2 \pm 0.9$ \\
\hline $1742(\mathrm{~F})$ & $51.1 \pm 13.3$ & $87.3 \pm 7.0$ & $6.1 \pm 1.6$ & $10.6 \pm 0.9$ & $5.8 \pm 1.6$ & $1.5 \pm 0.8$ \\
\hline $1743(\mathrm{~F})$ & $55.8 \pm 20.5$ & $83.8 \pm 19.2$ & $6.7 \pm 2.5$ & $10.1 \pm 2.3$ & $5.3 \pm 2.4$ & $1.9 \pm 2.3$ \\
\hline $1745(\mathrm{~F})$ & $56.1 \pm 13.5$ & $88.2 \pm 9.7$ & $6.7 \pm 1.6$ & $10.7 \pm 1.2$ & $5.2 \pm 1.6$ & $1.4 \pm 1.2$ \\
\hline Mean $^{\mathrm{a}}$ & $56.5 \pm 6.0$ & $85.5 \pm 3.9$ & $6.8 \pm 0.8$ & $10.3 \pm 0.5$ & $5.2 \pm 0.7$ & $1.7 \pm 0.5$ \\
\hline \multicolumn{7}{|c|}{ Pre-laying exodus } \\
\hline $1743(\mathrm{~F})$ & $56.6 \pm 1.4$ & $31.2 \pm 18.2$ & $7.0 \pm 1.8$ & $3.7 \pm 2.1$ & $5.3 \pm 1.7$ & $8.1 \pm 2.1$ \\
\hline
\end{tabular}

\section{At-sea distribution and movements}

Late chick-rearing period

During the chickrearing period, most wedge-tailed shearwater chicks are fed every day, and adult foraging trips last on average 1 or 2 d (Berlincourt 2006, Peck \& Congdon 2006). This is reflected in the relative proximity of the core foraging areas to the breeding colony. However, and despite the small sample size, females showed a broader distribution than males during late chick rearing, suggesting possible sex-related differences in foraging and/or provisioning behaviour. This agrees with the results of Peck \& Congdon (2006) that described longer foraging trips and lower provisioning rates in females of wedge-tailed shearwaters breeding in the southwestern Pacific Ocean. They suggested that inter-sexual competition (leading to niche/ habitat specialisation) at the foraging grounds was the most parsimonious explanation for the sex-specific differences observed in this monomorphic species. 


\section{Non-breeding period}

Wedge-tailed shearwaters showed 2 distinct strategies during the non-breeding period. Most birds were found on a distribution gradient along the equator, between $5^{\circ} \mathrm{N}$ and $10^{\circ} \mathrm{S}$. Some of the tracked individuals showed little dispersion, staying as close as $1000 \mathrm{~km}$ to Aride Island, while others commuted $3500 \mathrm{~km}$ to the Central Ocean Basin. Individual variation in distribution of foraging areas during the nonbreeding season has been described for several species of Procellariiformes (Croxall et al. 2005, Phillips et al. 2005, 2006, Shaffer et al. 2006, González-Sólis et al. 2007). Although this is intriguing, there is no evidence that even dramatic variation in dispersal tactics within a population reflects short- or long-term variation in success, or has any implication for timing of return or subsequent success of the individuals concerned (Croxall et al. 2005, Phillips et al. 2005, 2006).

Pre-breeding period

Although most wedge-tailed shearwaters start breeding in late September or October, adults return to Aride Island in mid-May or June. The first visits to land after the non-breeding period took place in a temporal window of ca. 3 wk for all tracked birds. An early return to the breeding colony is a way to avoid the occupation of nests by intruders and seems to be common among burrow-nester seabirds (Phillips et al. 2006). In our case, this early return is also probably related to the increase in primary productivity of the surrounding waters, which is an indicator of the abundance of food resources for seabirds (see next subsection). The distribution of wedge-tailed shearwaters during the prebreeding period largely overlapped that during late chick rearing. Given that during the pre-breeding period, shearwaters are not nearly as tied to central-place foraging as they are when provisioning chicks, although they do attend the colony to mate and prospect or defend nest sites, this suggests that foraging conditions within a relative short range of Aride Island are adequate for the needs of shearwaters during this time.

The only individual followed during a pre-laying foraging trip (exodus) of $22 \mathrm{~d}$ spent about $15 \mathrm{~d}$ of this in the Somali Basin. This was the only bird to spend a considerable proportion of time in this productive region. Although more coastal, this area is characterised by very deep waters, and is located at the edge of the continental shelf, which is commonly associated with strong upwelling. Egg formation is an energetically costly process in birds (Ricklefs 1974) and this result suggests that the exploitation of more productive waters by females may be particularly important dur- ing the pre-laying period. Nevertheless, more data from a larger sample size would be essential to confirm these results.

\section{At-sea distribution in relation to oceanography and abundance of subsurface predators}

Overall, and despite some individual variation, the tracked wedge-tailed shearwaters utilised deep, warm and relatively unproductive oceanic waters. Food availability in tropical marine environments is usually described as low and unpredictable, and considered to show limited seasonal variation (Harrison \& Seki 1987, Weimerskirch 2007). Nevertheless, in the Seychelles archipelago there is a clear seasonality in food availability, which seems to be directly related to phytoplankton blooms (Monticelli et al. 2007). Two blooms occur with some predictability each year: a small one from December to February, and the main one from May to August (Monticelli et al. 2007). These 2 periods of enhanced ocean productivity around the archipelago seem to play an important role in determining the breeding phenology and movements of wedge-tailed shearwaters. During both these periods, corresponding to chick rearing and pre-breeding, core areas of the distribution of wedge-tailed shearwaters are centred on Aride Island. In contrast with most other seabirds on the island (Bowler et al. 2002), wedge-tailed shearwaters breed during the austral summer, rearing their chicks at the time of the smaller phytoplankton bloom. At the end of the breeding season, and from March to at least mid-May, mean chl a concentrations are extremely low in most of the tropical Indian Ocean and it is then that wedge-tailed shearwaters disperse over a wider area. The early return to the colony, in late May to June, although also conditioned by the need to arrive early to defend nest sites, seems to be highly synchronised with this second peak in primary productivity in the surrounding waters.

During the non-breeding period, individual variation in distribution and habitat preferences was marked, and suggests a lack of specialisation on specific habitats or oceanographic features by tracked birds. This is likely to be because compared with temperate or polar seabirds that are often associated with oceanographic features such as fronts, eddies, shelf edges or upwelling, tropical seabirds seem to rely to a much greater extent on subsurface predators (Ballance \& Pitman 1999, Spear et al. 2001, Jaquemet et al. 2004). Previous studies in the western Indian Ocean have shown that wedge-tailed shearwaters usually associate in large flocks with yellowfin tuna Thunnus albacares and skipjack tuna Katsuwonus pelamis (S. Jaquemet pers. comm.), which facilitate feeding on juvenile goatfish (Mullidae) and flying squid 
(Ommastrephidae; Catry et al. in press). The distribution of wedge-tailed shearwaters, which is mostly restricted to between $5^{\circ} \mathrm{N}$ and $10^{\circ} \mathrm{S}$ in the area of influence of the ECC, corresponds closely to the distribution of catches of yellowfin and skipjack tuna by human fisheries (IOTC 2005, SFA 2006), which agrees with our predictions. As Spear et al. (2001) found for tropical piscivore seabirds in the Pacific Ocean, the affinity of shearwaters for the ECC is probably related to the distribution of surface-feeding tuna, which are associated with areas of deeper and well-stratified thermocline (Brill et al. 1999). Previous shipboard transects in the western and central Indian Ocean also recorded higher concentrations of wedgetailed shearwaters (between March and May) within the ECC (Bailey 1968).

Although some tracked shearwaters travelled $>3000 \mathrm{~km}$ to exploit the relatively deep, cooler and more productive waters of the Central Indian Basin (in relation to the western areas), contrary to our prediction, no bird travelled to the much more nutrient-rich waters of the Arabian Sea. Overall, the distribution of tracked individuals during the non-breeding and pre-breeding periods suggests that wedge-tailed shearwaters do not take advantage of foraging in very productive waters, such as the upwelling region off Somalia and Arabia. During the pre-breeding period, however, 3 ind. (including the one performing the pre-laying exodus) exploited the more nutrient-rich waters of the Somalia Basin. Nonetheless, these birds did not show fidelity to the area. Several authors consider that differences in water clarity drive differences in seabird foraging behaviour and that different adaptations may be needed for feeding in the clear blue water of the mid-ocean compared with more turbid, plankton-rich upwelling areas (Bailey 1968, Spear et al. 2001, 2007). In tropical marine environments, prey are concentrated in the water column during the day, avoiding the upper layer where high water clarity makes them highly susceptible to predators. Subsurface predators are therefore crucial for driving prey upwards and making them available to seabirds. In contrast, in highly productive waters where prey frequently aggregate near the sea surface in any case, such an association with subsurface predators is no longer necessary. Furthermore, upwelling regions usually concentrate high densities of foraging seabirds in which inter-specific competition tends to be higher (Ballance et al. 1997), which might be another reason the tracked birds tended to avoid the Somalian and Arabian coasts.

\section{Activity patterns}

The risk of predation, mainly by sharks, was previously pointed to as an important selective pressure for tropical seabirds not spending the night sitting on the sea surface (Weimerskirch et al. 2005). The presence of sharks has also been proposed as one of the factors explaining the absence of an important niche of pursuit divers among tropical seabirds (Spear et al. 2007). In the present study, during the non-breeding period, wedge-tailed shearwaters spent a very high proportion of the night resting on the water, suggesting that the risk of predation may be much lower than previously proposed. The higher feeding activity during the day is somewhat unsurprising given that tuna activity, which seems to be important for shearwater foraging, is limited to daylight (Roger 1994). Furthermore, foraging efficiency may be reduced at night because it is harder to see and catch prey at low light levels (Catry et al. 2004, Phalan et al. 2007). Paradoxically, the female tracked during the pre-laying exodus spent a much lower proportion of the night sitting on the sea surface. This suggests that females increase their foraging effort during the pre-laying period, although the fact that activity patterns during daylight remained unchanged does not support this explanation. It is possible, however, that foraging activity is limited by physiological processes, e.g. digestion, requiring periods of inactivity. Nevertheless, the use of a different feeding strategy and/or the targeting of different prey may be the most plausible explanation for the differences recorded, and could be an adaptation to the different characteristics of the area exploited-deeper waters, lower SST and significantly higher productivity. The lack of studies on activity patterns of Procellariiformes during the non-breeding period precludes direct comparisons. Grémillet et al. (2000) showed that nonbreeding black-browed albatrosses Diomedea melanophris spent more time on the water than breeding individuals in the Falkland Islands; however, no data on activity during daylight and darkness periods were presented. Four species of albatrosses studied during different phases of the breeding period at South Georgia spent less time on the water during daylight (14.3 to $39.8 \%$; Phalan et al. 2007) than did wedgetailed shearwaters in the present study.

\section{Foraging strategies of tropical pelagic seabirds}

Previous studies on the at-sea distribution of albatrosses and petrels during the non-breeding period in both temperate and polar environments have described relatively long migrations from breeding grounds towards areas of high primary productivity associated with coastal ocean currents and/or continental shelves (Croxall et al. 2005, Phillips et al. 2005, 2006, Shaffer et al. 2006, González-Sólis et al. 2007). By comparison, wedge-tailed shearwaters from Aride Island showed short-distance movements and ex- 
ploited relatively unproductive oceanic waters. The distribution of shearwaters largely matched the distribution of yellowfin and skipjack tunas, emphasising the importance of the association with subsurface predators rather than associations with physical oceanographic features that enhance primary productivity. The present study therefore highlights the differences in foraging ecology of tropical versus temperate and polar seabird species during the little-known nonbreeding season.

\section{Implications for conservation}

Tuna catches in the Indian Ocean have dramatically increased since the early 1980s (IOTC 2005). The main impact of fisheries on tropical shearwaters in the Indian Ocean, in contrast to the situation for subtropical, temperate and polar Procellariiformes (e.g. Skillman \& Flint 1997, Baker \& Wise 2005, Phillips et al. 2005, 2006), is probably not the risk of incidental mortality on longlines. Stock assessments suggest that if current fishing effort and catches are maintained, tuna populations will soon fall to levels below those of sustainable yield (IOTC 2005). If tuna populations are depleted, prey availability to tropical seabirds associated with tuna schools will decrease accordingly. Therefore, current and future fisheries policies and practices in the Indian Ocean have important implications for the conservation of tropical wedge-tailed shearwaters.

Acknowledgements. We thank the Island Conservation Society (ICS) for permission to work on Aride Island. B. Sampson provided valuable help during logger retrieval. Two anonymous referees provide valuable revisions to the manuscript. T.C. was funded by a Portuguese doctoral grant from Fundação para a Ciência e Tecnologia (SFRH/BD/16706/2004). This work is part of a regional programme on seabirds as bioindicators of the marine environment, funded by the Western Indian Ocean Marine Science Association (Marine Science for Management Grant, MASMA/AG/2004/04), and by the French Agency for Research (Programme REMIGEANR Biodiversité 2005-011). This research was conducted with permission of the Seychelles Bureau of Standards, Republic of Seychelles.

\section{LITERATURE CITED}

Ashmole NP (1971) Seabird ecology and the marine environment. Avian Biol 1:223-286

Bailey RS (1968) The pelagic distribution of sea-birds in the western Indian Ocean. Ibis 110:493-519

Baker GB, Wise BS (2005) The impact of pelagic longline fishing on the flesh-footed shearwater Puffinus carneipes in eastern Australia. Biol Conserv 126:306-316

Ballance LT, Pitman RL (1999) Foraging ecology of tropical seabirds. In: Adams NJ, Slotow RH (eds) Proc 22nd Int Ornithol Congr, August 1998, Durban. BirdLife South Africa, Johannesburg, p 2057-2071
Ballance LT, Pitman RL, Reilly SB (1997) Seabird community structure along a productivity gradient: importance of competition and energetic constraint. Ecology 78: 1502-1518

Berlincourt M (2006) Strategie de reproduction et ecologie alimentaire du puffin du Pacifique Puffinus pacificus aux Seychelles (Ile Cousin). MPhil thesis, Université de La Réunion, Saint Denis

Birdlife International (2007) Species factsheet: Puffinus pacificus. www.birdlife.org/datazone/species/index.html

> Bowler J, Betts M, Bullock I, Ramos JA (2002) Trends in seabird numbers on Aride Island Nature Reserve, Seychelles 1988-2000. Waterbirds 25:26-38

> Brill RW, Block BA, Boggs CH, Bigelow KA, Freund EV, Marcinek DJ (1999) Horizontal movements and depth distribution of large adult yellowfin tuna (Thunnus albacares) near the Hawaiian Islands, recorded using ultrasonic telemetry: implications for the physiological ecology of pelagic fishes. Mar Biol 133:395-408

Burger AE, Lawrence AD (2000) Seabird monitoring handbook for Seychelles: suggested methods for censusing seabirds and monitoring their breeding performance. Birdlife Seychelles, Mahé, Seychelles

Catry P, Phillips RA, Phalan B, Silk JRD, Croxall JP (2004) Foraging strategies of grey-headed albatrosses Thalassarche chrysostoma: integration of movements, activity and feeding events. Mar Ecol Prog Ser 280:261-273

Catry T, Ramos JA, Jaquemet S, Faulquier L and others (2009) Comparative foraging ecology of a tropical seabird community of the Seychelles, western Indian Ocean. Mar Ecol Prog Ser 374:259-272

Croxall JP, Silk JRD, Phillips RA, Afanasyev V, Briggs DR (2005) Global circumnavigations: tracking year-round ranges of nonbreeding albatrosses. Science 307:249-250

Dunlop JN, Surman CA, Wooller RD (2001) The marine distribution of seabirds from Christmas Island, Indian Ocean. Emu 101:19-24

> González-Sólis J, Croxall JP, Oro D, Ruiz X (2007) Transequatorial migration and mixing in the wintering areas of a pelagic seabird. Front Ecol Environ 5:297-301

Grémillet D, Wilson RP, Wanless S, Chater T (2000) Blackbrowed albatrosses, international fisheries and the Patagonian Shelf. Mar Ecol Prog Ser 195:269-280

Hamer KC, Humphreys EM, Garthe S, Hennicke J and others (2007) Annual variation in diets, feeding locations and foraging behaviour of gannets in the North Sea: flexibility, consistency and constraint. Mar Ecol Prog Ser 338: 295-305

Harrison P (1983) Seabirds: an identification guide. Christopher Helm, London

Harrison CS, Seki MP (1987) Trophic relationships among tropical seabirds at the Hawaiian Islands. In: Croxall JP (ed) Seabirds: feeding ecology and role in marine ecosystems. Cambridge University Press, Cambridge, p 305-326

Hill RD (1994) Theory of geolocation by light levels. In: Le Boeuf BJ, Laws RM (eds) Elephant seals: population ecology, behaviour and physiology. University of California Press, Berkeley, p 227-236

IOTC (2005) Report of the eighth session of the Scientific Committee. Indian Ocean Tuna Comission, Victoria, Seychelles

Jaquemet S, Le Corre M, Weimerskirch H (2004) Seabird community structure in a coastal tropical environment: importance of natural factors and fish aggregating devices (FADs). Mar Ecol Prog Ser 268:281-292

Mallory ML, Akearok JA, Edwards DB, O'Donovan K, Gilbert CD (2008) Autumn migration and wintering of northern 
fulmars (Fulmarus glacialis) from the Canadian high Arctic. Polar Biol 31:745-750

Monticelli D, Ramos JA, Quartly GD (2007) Effects of annual changes in primary productivity and ocean indices on breeding performance of tropical roseate terns in the western Indian Ocean. Mar Ecol Prog Ser 351:273-286

Newton I (2008) The migration ecology of birds. Academic Press, London

Peck D, Congdon B (2006) Sex-specific chick provisioning and diving behaviour in the wedge-tailed shearwater Puffinus pacificus. J Avian Biol 37:245-251

Phalan B, Phillips RA, Silk JRD, Afanasyev V and others (2007) Foraging behaviour of four albatross species by night and day. Mar Ecol Prog Ser 340:271-286

Phillips RA, Silk JRD, Croxall JP, Afanasyev V, Briggs DR (2004) Accuracy of geolocation estimates for flying seabirds. Mar Ecol Prog Ser 266:265-272

Phillips RA, Silk JRD, Croxall JP, Afanasyev V, Bennett VJ (2005) Summer distribution and migration of nonbreeding albatrosses: individual consistencies and implications for conservation. Ecology 86:2386-2396

Phillips RA, Silk JRD, Croxall JP, Afanaysev V (2006) Yearround distribution of white-chinned petrels from South Georgia: relationships with oceanography and fisheries. Biol Conserv 129:336-347

Phillips RA, Catry P, Silk JRD, Bearhop S, McGill R, Afanasyev V, Strange IJ (2007) Movements, winter distribution and activity patterns of Falkland and brown skuas: insights from loggers and isotopes. Mar Ecol Prog Ser 345: 281-291

Pocklington R (1979) An oceanographic interpretation of seabird distributions in the Indian Ocean. Mar Biol 51: 9-21

Ricklefs RE (1974) Energetics of reproduction in birds. In: Paynter RA (ed) Avian energetics. No. 15 Nuttall Ornithol Club, Cambridge, p 152-292

Roger C (1994) Relationship among yellowfin and skipjack tuna, their prey and plankton in the tropical west Indian Ocean. Fish Oceanogr 3:133-144

Rogers AEF (1975) Movements of the wedge-tailed shearwater off the coast of New South Wales. Emu 75:178-180

Editorial responsibility: Yves Cherel, Villiers-en-Bois, France
SFA (2006) Annual report. Seychelles Fishing Authority, Victoria, Seychelles

Shaffer SA, Tremblay Y, Awkerman JA, Henry RW and others (2005) Comparison of light- and SST-based geolocation with satellite telemetry in free-ranging albatrosses. Mar Biol 147:833-843

Shaffer SA, Tremblay Y, Weimerskirch H, Scott D and others (2006) Migratory shearwaters integrate oceanic resources across the Pacific Ocean in an endless summer. Proc Natl Acad Sci USA 103:12799-12802

Skillman R, Flint EN (1997) Mortality of Laysan and blackfooted albatrosses in the Hawaii pelagic longline fishery. Pac Seabirds 24:23

> Spear LB, Ainley DG (2005) At-sea behaviour and habitat use by tropicbirds in the eastern Pacific. Ibis 147:391-407

Spear LB, Balance LT, Ainley DG (2001) Response of seabirds to thermal boundaries in the tropical Pacific: the thermocline versus the Equatorial Front. Mar Ecol Prog Ser 219: $275-289$

Spear LB, Ainley DG, Walker WA (2007) Foraging dynamics of seabirds in the eastern tropical Pacific Ocean. Stud Avian Biol 35, Cooper Ornithological Society, Los Angeles, CA

Tomczak M, Godfrey JS (2003) Regional oceanography: an introduction, 2nd edn. Daya Publishing House, Delhi

Weimerskirch H (2007) Are seabirds foraging for unpredictable resources? Deep-Sea Res II 54:211-223

Weimerskirch H, Wilson RP (2000) Oceanic respite for wandering albatrosses. Nature 406:955-956

- Weimerskirch H, Le Corre M, Ropert-Coudert Y, Kato A, Marsac F (2005) The three-dimensional flight of redfooted boobies: adaptations to forage in a tropical environment? Proc R Soc Lond B 272:53-61

Weimerskirch H, Le Corre M, Marsac F, Barbraud C, Tostain O, Chastel O (2006) Postbreeding movements of frigatebirds tracked with satellite telemetry. Condor 108:220-225

Wilson RP, Ducamp JJ, Rees G, Culik BM, Niekamp K (1992) Estimation of location: global coverage using light intensity. In: Priede IM, Swift SM (eds) Wildlife telemetry: remote monitoring and tracking of animals. Ellis Horward, Chichester, p 131-134

Submitted: June 17, 2008; Accepted: August 28, 2008

Proofs received from author(s): January 15, 2009 